・论坛・ 中国国家公园试点专题

\title{
云南香格里拉普达措国家公园体制试点经验
}

\author{
杨宇明 ${ }^{1}$, 叶文 ${ }^{2}$, 孙鸿雁 $^{3^{*}}$
}

1. 云南省林业和草原科学院, 昆明 650201; 2. 西南林业大学, 昆明 650224; 3. 国家林业和草原局国家公园规划研究中心, 昆明 650031

杨宇明, 叶文, 孙鸿雁 (2021) 云南香格里拉普达措国家公园体制试点经验. 生物多样性, 29, 325-327. doi: 10.17520/biods.2021038.

Yang YM, Ye W, Sun HY (2021) Experience in the Pudacuo National Park system pilot in Shangri-La, Yunnan. Biodiversity Science, 29, 325-327. doi: 10.17520/biods.2021038.

\section{Experience in the Pudacuo National Park system pilot in Shangri-La, Yunnan}

Yuming Yang ${ }^{1}$, Wen $\mathrm{Ye}^{2}$, Hongyan Sun ${ }^{3 *}$

1 Yunnan Academy of Forestry and Grassland, Kunming 650201

2 Southwest Forestry University, Kunming 650224

3 National Forestry and Grassland Administration, National Park Planning and Research Center, Kunming 650031

普达措国家公园位于滇西北“三江并流”世界遗 产地, 这里是北半球新特有物种的分化中心, 也是 全球34个生物多样性热点地区之一。滇西北的生物 多样性与生态环境虽然丰富, 却十分脆弱(吴良镛, 2000)。同时滇西北是典型的少数民族聚居的偏远地 区, 在保护力度不断加强的同时, 也限制了当地群 众的传统生计与地区的经济发展。本世纪初在云南 省人民政府指导下，迪庆藏族自治州人民政府与西 南林业大学生态旅游学院合作, 针对滇西北世界遗 产地保护与旅游资源开发利用的矛盾, 对寻求生态 保护与发展双赢的模式进行了大胆探索, 并于2006 年1月由云南省人民政府倡导在西南林业大学成立 了国家公园发展研究所, 开始了滇西北创建国家公 园的规划研究。普达措国家公园体制试点区是在云 南碧塔海省级自然保护区 $141 \mathrm{~km}^{2}$ 的基础上, 将保 护区面积扩大到 $602 \mathrm{~km}^{2}$, 把更大范围的森林、湿 地、草甸、野生动物栖息地、传统民族村落等纳入 保护区域, 完善了《普达措国家公园总体规划》, 合 理划定公园区域内的功能分区, 制定产业准入清单, 关停了公园范围内及周边的尾矿库并开展生态修 复。试点建设以来启动国家公园本底调查, 完成了
十余项专题科学考察, 全面掌握了普达措国家公园 试点区范围内的重要资源本底, 以及解说词、居民 点调控等数10项专项规划编制(杨劼, 2020)。实践证 明, 普达措国家公园的建立符合滇西北生物多样性 保护与社区生计可持续发展的共同需要, 有利于正 确处理遗产地保护与地方经济发展的关系, 可促成 生态保护、经济发展与社会进步的多赢。因此, 解 决各方利益群体需求是普达措国家公园体制试点 的核心问题。

滇西北丰富而脆弱的生态环境迫切需要加强 保护, 同时又要加快藏区经济社会发展, 特别是 1999年滇西北全面实施天然林保护工程后，过去主 要依靠采伐林木为主的地方财政收入比禁伐前下 降了 60\%-90\%，农牧民收入受到严重影响，不得不 进入碧塔海省级自然保护区以开发生态旅游为生 计(杨宇明, 2017, 光明日报2017.04.02第05版)。既 有效保护世界遗产地，又要保障社区群众的生存与 地方经济可持续发展, 促使保护工作者必须探索建 立有效保护与可持续发展共赢的保护地新模式 ${ }^{\circledR}$ 。

2006年，云南省人民政府根据滇西北的特殊实 际, 在寻求实现保护与发展双赢的路径中进行了大

收稿日期: 2021-01-28; 接受日期: 2021-03-15

* 通讯作者 Author for correspondence. E-mail: 653490200@qq.com

(1) 叶文, 杨宇明 (2020) 《普达措国家公园环保督查前后情况报告》 (来源: 国家林业和草原局) 
胆探索，率先在滇西北建立大陆首个国家公园— 香格里拉普达措国家公园; 2008年列为国家林业局 试点; 2015年列为全国10处国家公园体制试点之 一。普达措国家公园始终坚持“政府主导、保护优 先、管经分离、社区参与”的原则, 以规划为引领, 协同发展为指导, 制定并建立起了生态保护与经营 管理的法规体系和高效运转的管理机构, 形成了地 方政府、保护管理机构、旅游经营企业和社区村民 委员会多方利益共享机制, 探索出一条在滇西北生 物多样性极为丰富、生态极度脆弱、经济发展水平 严重滞后的“三江并流”世界自然遗产地，生物多样 性得到有效保护与经济社会协同发展的双赢之路, 实现了保护实施有力、发展不损坏资源与环境, 人 与自然和谐发展的目标, 成为集保护、科研、生态 旅游、村民生计和地方经济为一体的协同保护与发 展示范区。

\section{加强了对重要保护对象的保护力度}

国家公园设立后，牵马载客旅游被取缔，以环 保车辆代替马匹的交通方式和沿栈道徒步的游览 线路，防止了马匹对高山草甸的践踏和湖水的污 染。试点以来所开展的旅游活动被严格限制在栈道 内和一些环境承载力较强的区域, 旅游活动方式对 生态环境的影响显著减少, 森林、草甸和湿地得到 了有效的保护, 碧塔海高原湖泊湿地的生态环境及 湖泊水质较试点前得到显著改善。根据迪庆州环境 监测站2017-2020年的数据, 国家公园试点后碧塔 海水质由三类水质提升到一类。从2006年普达措国 家公园建设以来，未发生过森林火灾，湖水水质始 终保持在一类水，负氧离子在 12,000 个 $/ \mathrm{cm}^{3}$ 以上, 碧塔海高原湖泊特有鱼类中甸叶须鱼(Ptychobarbus chungtienensis) 和极濒危物种高寒水韭 (Isoetes hypsophila) 以及越冬的保护候鸟黑颈鹤 (Grus nigricollis)和斑头雁(Anser indicus)等珍稀濒危特有 物种得到了有效保护, 种群数量在不断增长。

2016年以来, 利用中央预算内湿地保护和基础 设施建设项目资金共计 1.1 亿元，社会资本数亿元， 按试点要求实施了封山育林和植被修复 2 万余亩, 建立完善了保护监测网站(点)、巡护步道、森林防 火通道及栈道等管护设施和垃圾、污水收集处理系 统，建立了科普宣教中心、自然教育基地和监测站 (点)等公益性设施以及环保车和宣传解说牌, 曾经
被日均量达2,000余载人马匹穿行践踏的草甸或毁 坏的森林, 如今已建立了环保车通道, 恢复了自然 生态原貌，显著提升了国家公园的管护能力与成效 (杨劼, 2020)。

\section{把社区村民的生计纳入试点建设的管理目}

普达措国家公园建设试点最大的成功之处，就 是将公园的建设发展目标与社区村民的生计紧密 结合起来，把社区可持续发展纳入了试点建设的管 理目标。试点坚持“社区参与、惠益共享”的基本原 则，制定了社区可持续替代生计发展计划与村民优 先就业政策，建立了长期帮扶机制。过去的牵马人 经过培训成为了环保车驾驶员; 选取社区村民中有 中等以上文化程度的女青年开展了专项培训，成为 了国家公园的导游; 优先录用社区村民成为保安和 保洁员。普达措国家公园直接或间接为社区提供就 业岗位350个，其中正式合同工95人，占公园正式 编制总人数的 $47.7 \%$; 长期临时用工 80 人，占公园 临时用工的 $53.3 \%$; 补偿协议内经营公司投资的经 营性项目直接或间接参与的社区村民约 155 人，真 正意义上体现了“社区参与式管理”与“惠益共享”的 原则，实现了国家公园与社区的共赢发展的目标。 同时，出台了《普达措国家公园旅游反哺社区发展 实施方案》，每年从旅游收入中拿出 1,500 万元资金, 专项用于3,696名社区居民的直接经济补偿和教育 资助，对未能直接参与管理的农户或居民给予经济 补贴 ${ }^{(1)}$ 。

\section{发挥以教育促脱贫的重要功能}

普达措国家公园建立前的碧塔海省级自然保 护区内和周边的社区是云南藏区最贫困的地区之 一, 粮食都需要国家救济, 国家公园试点的直接带 动和间接反哺，已经使该地区全面实现脱贫。在当 地政府的推动下，经营公司大力投入教育补助，社 区村民辍学、就业难等问题得到了有效的解决。通 过教育补助受益的社区村民显著提高了知识水平 与教育素质，提高了就业能力，公司在用人时与社 区形成了相应的利益链，利用教育补助培养出的社 区人才，在同等条件下优先录用，增加了就业机 会。在以上政策带动下社区村民经济收入得到大幅

(1) 叶文, 杨宇明 (2020) 《普达措国家公园环保督查前后情况报告》 (来源: 国家林业和草原局) 
提高, 从而改变了不重视教育的传统思想, 每个家 庭都开始积极培养下一代就读于各种专业院校, 且 第一次培养出了大学本科毕业生, 有效促进了社区 与国家公园的和谐稳定与高质量发展。

国家公园试点后有力带动了区内和周边贫困 社区的发展, 对实施脱贫攻坚、能力建设和科普宣 教产生了显著成效, 为当地生态环境和生物多样性 保护与经济社会和谐发展做出了重要贡献。

\section{4 见证了“绿水青山就是金山银山”}

普达措国家公园试点后, 园内和周边社区村民 的居住、交通、生活、教育条件得到显著改善, 实 现了滇西北地区原住民在天然林禁伐和国家公园 退耕、禁牧后由传统农牧业变为生态管护与生态旅 游服务的替代生计转变。国家公园聘请了相关领域 的专家开展了能力建设培训, 把农牧民变为国家公 园的管护者, 不仅使国家公园的资源环境和主要保 护对象得到了有效保护, 而且生态旅游也得到科学 规范的发展，2012-2019年实现旅游收入18.9亿元, 社区村民户均收入从 2 万元增加到 10 万元, 实现了 国家公园生态保护与社区村民生产、生活的紧密融 合与共赢。国家公园保护成效的提高与经济效益的 同步增长, 使村民意识到保护好普达措国家公园的 森林、湖泊、草甸和生物多样性, 能够为当地带来 巨大的生态、经济和社会效益, 村民从过去的被动 保护, 变为自发的主动保护, 践行了 “绿水青山就 是金山银山”理论在滇西北的实例。

滇西北“三江并流”世界遗产地的生态旅游发展 与生态环境质量密不可分, 国家公园的自然生态资 源保护模式，与旅游业和农林牧业等产业之间具有 着相互促进、相互补充的良性互动关系。国家公园 是一种发展和保护共赢的保护地模式, 可有效缓解
生态旅游开发与生态环境和生物多样性保护的矛 盾, 通过充分挖掘和高效保护自然生态与文化遗产 资源, 有利于从整体上促进当地生态资源保护与生 态文化旅游的融合发展。因此, 在滇西北自然与文 化资源禀赋极其丰富多样，而生态环境极度脆弱的 地区, 通过国家公园的建设, 完全可以将生态文化 旅游培育成滇西北“三江并流”世界遗产地国民经济 的支柱产业，逐步替代矿产、水电和重化工等工业， 可以学习新西兰绿色发展的道路: 不经历“先污染、 后治理; 先破坏、后修复”的传统发展模式, 走出一 条不经过工业化而进入现代化的绿色发展之路。

致谢: 特别感谢云南省林业和草原局宣传中心副主 任杨女士，为本文提供了普达措国家公园试点建 设验收评估总结和相关数据; 云南省林业和草原局 保护地处、湿地处和普达措国家公园管理局等单位 和个人, 对作者的调研给予了大力支持与帮助, 在 此一并致以诚挚的谢意。

\section{参考文献}

Wu LY (2000) Study on Sustainable Development Planning of Human Settlement Environment in Northwest Yunnan. Yunnan University Press, Kunming. (in Chinese) [吴良镛 (2000) 滇西北人居环境可持续发展规划研究. 云南大学 出版社, 昆明.]

Yang J (2020) The Pudacuo National Park system is a pilot project to explore a win-win situation between ecology and people's livelihood. China Green Times, July 1, 2020. (in Chinese) [杨劼 (2020) 普达措国家公园体制试点探索生 态与民生共赢. 绿色时报, 2020 年 7 月 1 日第 2 版.] https://www.greentimes.com. (accessed on 2020-07-01)

(责任编委: 徐卫华 责任编辑: 时意专) 